\title{
INFLUENCE OF ROOTSTOCKS ON Fusarium WILT, NEMATODE INFESTATION, YIELD AND FRUIT QUALITY IN WATERMELON PRODUCTION
}

\author{
Influência de porta-enxertos sobre a murcha de Fusarium, infestação de nematóides, \\ rendimento e qualidade de frutos na produção de melancia
}

\author{
Juan Carlos Álvarez-Hernández ${ }^{1}$, Javier Zaragoza Castellanos-Ramos² ${ }^{2}$ César Leobardo Aguirre-Mancilla ${ }^{1}$, \\ María Victoria Huitrón-Ramírez ${ }^{3}$, Francisco Camacho-Ferre ${ }^{4}$
}

\begin{abstract}
Cucurbita maxima x Cucurbita moschata rootstock are used to prevent infection with Fusarium oxysporum f. sp. niveum in watermelon production; however, this rootstock is not effective against nematode attack. Because of their vigor, the grafted plants can be planted at lower plant densities than the non-grafted plants. The tolerance to Fusarium oxysporum f. sp. niveum and Meloidogyne incognita was assessed in watermelon plants grafted onto a hybrid of Citrullus lanatus cv Robusta or the Cucurbita maxima x Cucurbita moschata cv Super Shintoza rootstocks. The densities of plants were 2083 and 4166 plants ha $^{-1}$. Non-grafted watermelons were the controls. The Crunchy Red and Sangría watermelon cultivars were used as the scions, it the latter as a pollinator. The experiments were performed for two production cycles in soils infested with Fusarium oxysporum f. sp. niveum and Meloidogyne incognita. The incidence of Fusarium oxysporum f. sp. niveum was significantly greater in the non-grafted than in the grafted plants. The grafted plants presented similar resistance to Fusarium regardless of the rootstock. The root-knot galling index for Meloidogyne incognita was significantly lower in plants grafted onto Citrullus lanatus cv Robusta than onto the other rootstock. The yields of plants grafted onto Citrullus lanatus $c v$ Robusta grown at both plant densities were significantly higher than in the other treatments.
\end{abstract}

Index terms: Citrullus lanatus; grafting; triploid; Fusarium oxysporum; root-knot nematodes.

\begin{abstract}
RESUMO
A enxertia de Cucurbita maxima x Cucurbita moschata tem sido usada para prevenir problemas com Fusarium oxysporum f. sp. niveum na produção de melancia embora não seja efetivo contra ataque de nematóides. Em razão de seu vigor, plantas enxertadas podem ser plantadas em densidade mais baixa do que as plantas não enxertadas. A tolerância a Fusarium oxysporum $\mathrm{f}$. sp. niveum e Meloidogyne incognita foi avaliada em plantas de melancia enxertadas em híbridos de Citrullus lanatus cv Robusta

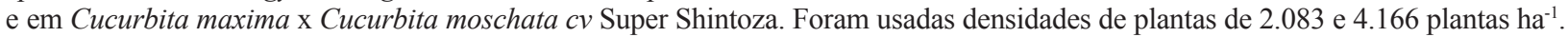
Como testemunhas usou-se plantas não enxertadas. Os cultivares de melancia Crocantes vermelhas e Sangria foram usados como polinizador. O experimento foi realizado em dois ciclos, sendo instalado em solo infestado com Fusarium oxysporum f. sp. niveum e Meloidogyne incognita. A incidência de Fusarium oxysporum f. sp. niveum foi, significativamente, maior em plantas não enxertadas. Plantas enxertadas apresentaram resistência semelhante ao Fusarium independentemente do porta-enxerto. O índice de galhas de Meloidogyne incognita foi significativamente menor em plantas enxertadas em Citrullus lanatus cv Robusta. As maiores diferenças significativas em relação aos demais tratamentos foram observadas em ambas as densidades de plantas enxertadas pela produtividade das plantas enxertadas em Citrullus lanatus cv Robusta.
\end{abstract}

Termos para indexação: Citrullus lanatus; enxertia; triplóides; Fusarium oxysporum; nematóides das galhas.

\section{INTRODUCTION}

One of the primary challenges to watermelon production worldwide is the damage caused by Fusarium oxysporum f. sp. niveum (Boughalleb et al., 2008; Dau et al., 2009). The disinfection of soils with methyl bromide was initially successful; however, with time, the disease became resistant, and the disinfectant applications were no longer effective. The use of Fusarium-resistant rootstocks provides an alternative to soil chemical applications. The most widely used rootstocks are the interspecific hybrids of Cucurbita maxima x Cucurbita moschata (Keinath; Hassell, 2014; King et al., 2008; Miguel et al., 2004). However, this rootstock is vulnerable to attack by Meloidogyne incognita (Huitron et al., 2007; Lee; Oda, 2003), a nematode species that causes numerous problems in watermelon production,

\footnotetext{
${ }^{1}$ Tecnológico Nacional de México - Instituto Tecnológico de Roque - Celaya - Guanajuato - México

${ }^{2}$ Tecnológico Nacional de México - Instituto Tecnológico de Roque - Carretera Celaya-Juventino Rosas - C.P. 38110 - Apartado Postal 508 - Celaya Guanajuato - México - javier.castellanos.ramos@gmail.com

${ }^{3}$ Tecnológico Nacional de México - Instituto Tecnológico de Colima - Colima - México

${ }^{4}$ University of Almeria - Advanced Polytechnic School - Almería - Spain

Received in january 14, 2015 and approved in april 27, 2015
} 
including root-knot damage and lower yields (Del PradoVera; Tovar-Soto; Hernández, 2001).

Thies and Levi (2003) assessed Citrullus colocynthis, Citrullus lanatus var. citroides and Citrullus lanatus var. lanatus for tolerance to nematodes by measuring the levels of root-knot galling. In most cases, Citrullus lanatus var. lanatus was vulnerable to nematode attack with a galling index that ranged between 5 and 9 ; the scale is from 1 to 9 , and 1 indicates zero root-knot galling. The Citrullus colocynthis was highly vulnerable to nematode attack with a root-knot galling index that ranged from 8.5 to 9. The Citrullus lanatus var. citroides genotypes displayed moderate resistance with a rootknot galling index between 3.1 and 4, which indicated that this rootstock was a potential source of nematode resistance. Thies and Levi (2007) performed greenhouse trials with soils that were infested with nematodes and they concluded that there was great genetic variability within Citrullus lanatus var. citroides for tolerance to Meloidogyne incognita and $M$. arenaria. Therefore, generalizations on the tolerance to nematodes cannot be applied to the different genotypes of this cultivar. The additional benefits of some rootstocks are increased tolerance to humidity and soil salinity, improved water and nutrient uptake and an increase in plant vigor (Lee; Oda, 2003; Rivero; Ruiz; Romero, 2003; Schwarz et al., 2010). An important factor to consider is the effect of the density of plants on the yields of grafted commercial cultivars. However, few studies have examined the effects of plant density on grafted watermelon yields. In Colima, Mexico, Huitrón-Ramírez, Ricardez-Salinas and CamachoFerre (2009) determined that plant densities of 2778, 2083 and 1736 plants $\mathrm{ha}^{-1}$ were ideal to increase the fruit weights and yields in soils infected with the Melon Necrotic Spot Virus (MNSV).

The objectives of this study were to assess the resistance to Fusarium oxysporum $\mathrm{f}$. sp. niveum and Meloidogyne incognita in watermelon plants grafted onto Citrullus lanatus (cv Robusta) and C. maxima $x$ C. moschata $c v$ Super Shintoza rootstocks, using plant densities of 2083 and 4166 plants ha $^{-1}$ in two crop seasons. The yields and fruit quality were also assessed.

\section{MATERIAL AND METHODS}

\section{Experimental site}

The experiment was conducted during the 2011-2012 and the 2012-2013 crop seasons in a field located on Ciudad Morelos communal land in Parácuaro, Michoacán, Mexico (19 00' 53" North; $102^{\circ} 16^{\prime} 44^{\prime \prime}$ West). According to previous microbiological testing and the pathological history of the field, the soil contained Fusarium oxysporum f. sp. niveum and Meloidogyne incognita.

\section{Germplasms and seed germination}

The germplasms used as rootstocks were $c v$ Robusta (Citrullus lanatus) and $c v$ Super Shintoza ${ }^{\circledR}$ (an interspecific hybrid of squash; Cucurbita maxima x Cucurbita moschata), Zeraim Gedera, Israel. The scions were the cv Crunchy Red ${ }^{\mathbb{B}}$ (triploid), Harris Moran USA and the cv Sangría ${ }^{\circledR}$ (diploid) watermelons (Syngenta, USA), with the latter used as a pollinator. The seeds were sown in November 2011 and 2012 in 128 cell polystyrene trays with cell volumes of $46 \mathrm{~cm}^{3} /$ cell and were saturated with previously wet Growing Mix IVM substrate (Canadian sphagnum peat moss, Canada). The watermelon seeds were planted first, followed by the rootstocks six days later. The trays were immediately stacked and covered with black plastic to promote germination. After 48 hours, the trays with emerged seedlings were separated in preparation for further growth in the greenhouse. When the plants developed three true leaves and the stem diameters were similar, tongue-approach grafting was performed using lead tape to wrap the graft (Oda, 1995).

\section{Field preparation}

The soil was prepared by tillage, forming $1.0 \mathrm{~m}$ wide $\mathrm{x} 18.0 \mathrm{~m}$ long beds that were spaced $4 \mathrm{~m}$ apart. Subsoil fertilization was applied. Soil samples were collected in both experiments for physical-chemical analysis to determine the rate of fertilization. The nutrients were applied in the following amounts: $177 \mathrm{~kg} \mathrm{~N}, 84 \mathrm{~kg}$ $\mathrm{P}$ and $32 \mathrm{~kg} \mathrm{~K}$ (first experiment); and $164 \mathrm{~kg} \mathrm{~N}, 112 \mathrm{~kg}$ $\mathrm{P}$ and $46 \mathrm{~kg} \mathrm{~K}$ (second experiment). The fertilizers were applied by drip irrigation, with the flow rate controlled by tensiometers installed in the soil at depths of 15 and 30 $\mathrm{cm}$ with a pressure range of 5-10 $\mathrm{kPa}$. A drip irrigation line was placed in the center of each bed, with a space of $0.15 \mathrm{~m}$ between the emitters that operated at a flow rate of $0.7 \mathrm{~L} \mathrm{~h}^{-1}$. A ninety-gage, $1.30 \mathrm{~m}$ wide black/white plastic mulch was placed on top of the beds with the white side placed upward. During the first year, the watermelon nodes that remained outside the mulched area developed adventitious roots; therefore, in the second year, a $2.6 \mathrm{~m}$ wide plastic strip was used to partially reduce the contact between the nodes and the soil. The transplantation into the field was performed on January $8^{\text {th }}, 2012$, and on December $26^{\text {th }}, 2012$.

\section{Experimental design}

The experiment was a completely randomized block design with six treatments and three replicates. The Ungrafted watermelons (UG), Grafted watermelons (G) onto C. maxima x C. moschata (CU), and grafted

Ciênc. Agrotec., Lavras, v. 39, n. 4, p. 323-330, jul./ago., 2015 
watermelons onto Citrullus lanatus $(\mathrm{CI})$ were all planted at densities of 4166 (HD) and 2083 plants ha ${ }^{-1}$ (LD). The choice of these plant densities was based on the density that was used in the region and on the vigor that these rootstocks provided to the scions. The treatments were as follows: 1 (G-CU-HD), 2 (G-CU-LD), 3 (G-CI-HD) and 4 (G-CI-LD). As the control $(\mathrm{C})$ treatments, watermelon plants that were ungrafted (UN) were planted at two densities for treatments 5 (C-UN-HD) and 6 (C-UN-LD), for a total of six treatments (Table 1). The distances between the plants were $4 \mathrm{~m} \times 0.6 \mathrm{~m}$ and $4 \mathrm{~m} \times 1.2 \mathrm{~m}$ for the HD and LD plantings, respectively. The area of the experimental units was $72 \mathrm{~m}^{2}$.

\section{Crop assessment}

The main shoot lengths were recorded with a tape measure, and the stem diameters were measured with a graduated vernier caliper. The root dry weight was measured with an AA-160 Bohemia digital scale from the Denver Instrument Company, NY, USA, at the completion of harvest. The plant health inspections were conducted weekly to identify symptoms and to record the incidence of Fusarium oxysporum and Meloidogyne incognita. For the fungus, the typical symptoms were wilting, leaf-yellowing, visible lesions at the union of the graft ("callus") or at the uncovered base of the plants in contact with the soil, and stem exudates. The cause of the symptoms was confirmed as Fusarium oxysporum by plant tissue analysis at the microbiology laboratories of CIIDIR-IPN in Jiquilpan, Michoacán, Mexico, and at IT-Roque in Celaya Guanajuato, Mexico. For the rootknot nematode (Meloidogyne incognita), in addition to the partial uncovering of lateral roots to detect galls, the typical signs of damage were premature wilt-like symptoms, diminished growth, and foliar chlorosis. After harvest, the roots from the damaged plants were separated from the soil to determine the extent of the damage using the Taylor and Sasser (1978) root-knot galling index: $0=$ zero galls; $1=$ two galls; $2=3$ to 10 galls; $3=11$ to 30 galls; $4=31$ to 100 galls; and $5=$ more than 100 galls per plant. Measures of quantitative production were recorded, including the number of set fruits per plant, which were counted by visual inspection. The fruits were weighed with a $120 \mathrm{~kg}$ capacity Oken ${ }^{\circledR}$ industrial scale, and the number of fruits per square meter and per plant and the yields in $\mathrm{kg} \cdot \mathrm{m}^{-2}$ were calculated for each replicate. The total yield included the fruits from both the triploid and diploid cultivars. The quality parameters were measured in five fruits chosen at random: soluble solids were determined with an HI 96801 Hanna refractometer (Woonsocket, RI, USA); pulp firmness was determined with a GY3 manual penetrometer (mainland China); pH was measured with a B-2013 Horiba (Kyoto, Japan) compact $\mathrm{pH}$ meter; and the rind thickness was measured with a caliper. The pulp thickness was measured using a graduated ruler. The moisture content was obtained by drying the pulp and then weighing it on an AA-160 Denver Instrument Company digital scale (Bohemia, NY, USA). The oven-drying time was approximately 3 hours.

\section{Data analysis}

The yield and quality data were analyzed using analysis of variance (ANOVA). The Fusarium infection and nematode incidence data that were recorded during the plant health inspections were based on the number of damaged plants and the intensity of the damage. The percentage of damaged plants was analyzed before performing arcsin transformation of the square root of the ratio and ANOVA. The root-knot galling index was measured by the percentage of damage severity and ANOVA. The SAS Institute (1997) statistical software package was used for the GLM procedure with Duncan's as the method for means separation $(\mathrm{P}=0.05)$.

Table 1: Treatment descriptions.

\begin{tabular}{ccccc}
\hline \multirow{2}{*}{ No. } & Treatment & \multicolumn{3}{c}{ Description } \\
\cline { 3 - 5 } & G-CU-HD & Rootstock & Grafted plant & $\begin{array}{c}\text { Plant density } \\
\left(\text { plants ha }^{-1}\right)\end{array}$ \\
\hline 1 & G-CU-LD & Super Shintoza & Yes & 4,166 \\
2 & G-CI-HD & Robusta & Yes & 2,083 \\
3 & G-CI-LD & Robusta & Yes & 4,166 \\
4 & C-UN-HD & --- & No & 2,083 \\
5 & C-UN-LD & --- & No & 4,166 \\
6 & & & & 2,083 \\
\hline
\end{tabular}




\section{RESULTS AND DISCUSSION}

The results for the pathology are shown in Table 2. Both rootstocks at both plant densities displayed resistance to Fusarium oxysporum, and there was no significant difference between the two rootstock treatments in either of the experiments for infection with Fusarium oxysporum.

Furthermore, in both experiments, the damage caused by Meloidogyne incognita to the watermelon grafted onto Citrullus lanatus cv Robusta was significantly less than that caused to the watermelon grafted onto the Super Shintoza rootstock or the non-grafted watermelon (Table 2).

The two rootstocks that were assessed were tolerant to Fusarium oxysporum f. sp. niveum (Dau et al., 2009; Keinath; Hassell, 2014). The greater degree of damage to the grafted plants that was observed during the first experiment was attributed to adventitious root development as a result of the narrow plastic mulch and high off-season rainfall. The watermelon stem nodes developed roots outside the mulched area, which allowed the pathogen's partial entrance into the plant. In the second experiment, the plastic mulch was sufficiently wide to eliminate adventitious root development. The damage to the nongrafted treatments was significantly greater than to the grafted plants, which confirmed the resistance of these rootstocks to this pathogen; however, the density of the plants did not effect this parameter (Table 2). For the damage caused by nematodes, the results in this study were consistent with those that were obtained by Thies and Levi (2003 and 2007). Those authors reported that Citrullus lanatus var. citroides had moderate tolerance to Meloidogyne incognita because it had less galling than the rootstocks Lagenaria siceraria and $C$. maxima $\mathrm{x} C$. moschata and the ungrafted watermelons. However, El-Wanis, Amin and Abdel (2013) evaluated four rootstocks including C. maxima x C. moschata in the presence of Meloidogyne incognita and Fusarium oxysporum and obtained gall ratings of 3 for the rootknot nematode damage, based on Taylor and Sasser (1978).

Table 2: The incidence of Fusarium oxysporum f. sp. niveum (Fon) and the root-knot nematode galling index for Meloidogyne incognita (Mi) in grafted and non-grafted triploid Crunchy Red watermelons.

\begin{tabular}{|c|c|c|c|c|c|}
\hline Treatment & \multicolumn{2}{|c|}{ Fon incidence } & \multicolumn{2}{|c|}{ Mi incidence } & Galling index \\
\hline \multicolumn{6}{|c|}{ 2011-2012 } \\
\hline 1 (G-CU-HD) & $0.41 \mathrm{ab}^{\mathrm{a}, \mathrm{b}}$ & $(16.66)^{\mathrm{c}}$ & $0.75 \mathrm{a}$ & $(46.66)$ & $3.93 \mathrm{a}$ \\
\hline 2 (G-CU-LD) & $0.36 b$ & (13.33) & $0.64 \mathrm{ab}$ & $(36.66)$ & $4.26 \mathrm{a}$ \\
\hline 3 (G-CI-HD) & $0.45 \mathrm{ab}$ & $(20.00)$ & $0.41 \mathrm{bc}$ & (16.66) & $0.76 \mathrm{~d}$ \\
\hline 4 (G-CI-LD) & $0.50 \mathrm{ab}$ & (23.33) & $0.26 \mathrm{c}$ & $(10.00)$ & $0.83 \mathrm{~d}$ \\
\hline 5 (C-UN-HD) & $0.64 \mathrm{a}$ & (36.66) & $0.61 \mathrm{ab}$ & (33.33) & $2.16 \mathrm{c}$ \\
\hline 6 (C-UN-LD) & $0.59 \mathrm{ab}$ & (33.33) & $0.57 \mathrm{ab}$ & $(30.00)$ & $2.70 \mathrm{~b}$ \\
\hline $\mathrm{P}$ & $*$ & & $* * *$ & & $* * *$ \\
\hline \multicolumn{6}{|c|}{$2012-2013$} \\
\hline 1 (G-CU-HD) & $0.21 b c$ & $(6.66)$ & $0.64 \mathrm{a}$ & $(36.66)$ & $2.63 b$ \\
\hline 2 (G-CU-LD) & $0.10 \mathrm{c}$ & $(3.33)$ & $0.52 \mathrm{a}$ & $(26.66)$ & $2.86 \mathrm{ab}$ \\
\hline 3 (G-CI-HD) & $0.10 \mathrm{c}$ & $(3.33)$ & $0.15 b$ & $(6.66)$ & $0.76 \mathrm{c}$ \\
\hline 4 (G-CI-LD) & $0.00 \mathrm{c}$ & $(0.00)$ & $0.15 b$ & $(6.66)$ & $0.70 \mathrm{c}$ \\
\hline 5 (C-UN-HD) & $0.61 \mathrm{a}$ & (33.33) & $0.71 \mathrm{a}$ & (43.33) & $3.06 \mathrm{a}$ \\
\hline 6 (C-UN-LD) & $0.52 \mathrm{ab}$ & $(26.66)$ & $0.64 \mathrm{a}$ & $(36.66)$ & $2.96 a$ \\
\hline $\mathrm{P}$ & $* * *$ & & $* *$ & & $* * *$ \\
\hline
\end{tabular}

$\mathrm{a} *, * *$ and $* * *$ represent significance at $\mathrm{P}<0.05,0.01$ and 0.001 , respectively. ${ }^{\mathrm{b}}$ Data subjected to arcsin transformation of the square root of the ratio. ${ }^{\mathrm{c}}$ Nontransformed data (\%) are shown in parentheses. 
The length of the main shoot was longer 85 days after transplanting (DAT) in the grafted plants (Table 3 ) than in the non-grafted plants. The lengths were not significantly different in the first experiment, but the lengths were significantly different in the second experiment. The stem diameter was significantly wider in the grafted plants than in the non-grafted plants in the two crop seasons (Table 3). The densities of the plants did not significantly affect the differences in stem diameters. However, the root dry weights were significantly different among the treatments in both experiments (Table 3). The watermelons grafted onto Citrullus lanatus cv Robusta had higher root dry weights than the non-grafted treatments and the treatments grafted onto Super Shintoza.

Moreover, the stem length and the stem diameter increased in the plants grafted to rootstocks compared with the non-grafted plants. Other studies found similar behaviors, although without the pathogens in the soil. Bekhradi, Kashi and Delshad (2011) measured the stem lengths of $c v$ Charleston Gray grafted onto C. maxima $\mathrm{x}$. moschata and for all cases, reported that the grafted plants had longer main stems than those in the non-grafted plants.

The number of fruits per plant was significantly different among the treatments in both crop seasons (Table 4). The results for the fruit weights (Table 4) were similar to the number of fruits per plant. The number of fruits $/ \mathrm{m}^{2}$ was highly significantly different between the two plant densities (Table 4). The plants grafted onto Citrullus lanatus at the high plant density produced $143 \%$ and $148 \%$ more fruits $/ \mathrm{m}^{2}$ compared with the low-plant-density grafted plants during the two years of the experiments.

Rootstocks provide vigor to scions to obtain a greater number of fruits with a greater weight than ungrafted plants. From a study of the grafted watermelons on two cultivars of C. maxima x C. moschata by Huitrón-Ramírez, Ricardez-Salinas and Camacho-Ferre (2009), the grafted plants produced higher-weight fruits than the non-grafted plants in soils that were contaminated with Olpidium bornovanus and MNSV. However, other studies did not report differences in the weights of fruits obtained from grafted and non-grafted plants (Bekhradi; Kashi; Delshad, 2011). Moreover, although the results for fruits per $\mathrm{m}^{2}$ in this study were similar to those reported by Huitrón-Ramírez, Ricardez-Salinas and Camacho-Ferre (2009), they did not find differences among the fruits at plant densities of 2778 , 2083 and 1736 plants ha $^{-1}$. The yield that was achieved with Citrullus lanatus $c v$ Robusta at the highest plant density was remarkable in this study, and we emphasize the low yields that were produced in the treatments with low densities of plants (2083 plants ha $\left.{ }^{-1}\right)$. Miguel et al. (2004) obtained higher yields with Reina de Corazones watermelons grafted onto $C$. maxima x $C$. moschata than with Reina de Corazones grafted onto Citrullus lanatus; however, the condition of the soil was not specified.

Notably, other research that evaluated the grafts of watermelon in soils infested with pathogens under various densities of plants did not report that the total yield of the triploid was more than that of the diploid, except for the work of HuitrónRamírez, Ricardez-Salinas and Camacho-Ferre (2009).

The production $\left(\mathrm{kg} \mathrm{m}^{-2}\right)$ of watermelons grafted onto Citrullus lanatus $c v$ Robusta significantly outperformed all other treatments (Table 5). The total production (considering the fruits obtained from the diploid and triploid plants) of the treatments grafted onto Robusta was significantly different from that of the other treatments (Table 5).

For the fruit quality, the soluble solids and the $\mathrm{pH}$ did not differ between the two experiments. However, the pulp firmness was significantly different in the two production cycles in which the fruits from the plants grafted onto Citrullus lanatus cv Robusta were more firm than the fruits from the plants that were grafted onto Super Shintoza or the fruits from the non-grafted plants (Table 6).

The soluble solid and $\mathrm{pH}$ values in this study were similar to those reported by other researchers (Bekhradi; Kashi; Delshad, 2011; Huitrón-Ramírez; Ricardez-Salinas; Camacho-Ferre, 2009; Miguel et al. 2004). Yetisir and Sari (2003) also assessed several rootstocks, including $C$. maxima $\mathrm{x} C$. moschata, and observed that the pulp firmness in the fruits from grafted plants was improved relative to that in the non-grafted plants. The rind thickness was greater in the ungrafted than in the grafted plants.

Notably, rootstocks with specific characteristics of resistance and/or tolerance to the primary phytosanitary problems in soils are used as an effective alternative in the growing of watermelons, even in the regions that have reduced the area grown under this crop, as has occurred in the Valley of Apatzingán in Michoacan, Mexico.

Therefore, this study provided a basis for the grafting of watermelons and offered an alternative solution for the management of the two primary phytosanitary problems that limit the production of watermelons.

The rootstocks that were tested had very specific behaviors in response to Fusarium oxysporum $\mathrm{f}$ sp. niveum and Meloidogyne incognita in the open field for the region that was under study. Of the rootstocks, the rootstock $c v$ Robusta Citrullus lanatus showed the greatest potential to manage both phytosanitary problems. Furthermore, although the chytridiomycete Olpidium bornovanus was absent in this study, this rootstock remains a promising alternative for the production of watermelons. 
Table 3: Length and diameter of the main shoot and dry weight of roots in grafted and non-grafted triploid Crunchy Red watermelons.

\begin{tabular}{|c|c|c|c|}
\hline Treatment & Main shoot length & Main shoot diameter & Root dry weight (g/plant) \\
\hline \multicolumn{4}{|c|}{$2011-2012$} \\
\hline 1 (G-CU-HD) & 450 & $1.35 \mathrm{ab}^{\mathrm{a}}$ & $9.30 \mathrm{c}$ \\
\hline 2 (G-CU-LD) & 461 & $1.36 \mathrm{ab}$ & $9.65 \mathrm{c}$ \\
\hline 3 (G-CI-HD) & 453 & $1.39 \mathrm{a}$ & $19.89 \mathrm{a}$ \\
\hline 4 (G-CI-LD) & 457 & $1.33 b$ & $21.62 \mathrm{a}$ \\
\hline 5 (C-UN-HD) & 425 & $1.21 \mathrm{c}$ & $12.43 b$ \\
\hline $6(\mathrm{C}-\mathrm{UN}-\mathrm{LD})$ & 440 & $1.20 \mathrm{c}$ & $12.80 \mathrm{~b}$ \\
\hline $\mathrm{P}$ & NS & $* * *$ & $* * *$ \\
\hline \multicolumn{4}{|c|}{$2012-2013$} \\
\hline 1 (G-CU-HD) & $461 \mathrm{a}$ & $1.34 \mathrm{ab}$ & $14.15 b$ \\
\hline 2 (G-CU-LD) & $471 \mathrm{a}$ & $1.33 \mathrm{ab}$ & $16.04 b$ \\
\hline 3 (G-CI-HD) & $460 \mathrm{a}$ & $1.36 \mathrm{a}$ & $22.43 a$ \\
\hline 4 (G-CI-LD) & $468 \mathrm{a}$ & $1.38 \mathrm{a}$ & $24.08 \mathrm{a}$ \\
\hline 5 (C-UN-HD) & $428 b$ & $1.22 \mathrm{c}$ & $14.11 \mathrm{~b}$ \\
\hline 6 (C-UN-LD) & $444 a b$ & $1.26 \mathrm{bc}$ & $13.95 b$ \\
\hline $\mathrm{P}$ & $*$ & $* *$ & $* * *$ \\
\hline
\end{tabular}

${ }^{a} \mathrm{NS},{ }^{*}, * *$ and ${ }^{* * *}$ represent nonsignificance or significance at $\mathrm{P}<0.05,0.01$ and 0.001 , respectively.

Table 4: Quantitative traits of grafted and non-grafted triploid Crunchy Red watermelons.

\begin{tabular}{|c|c|c|c|c|c|}
\hline Treatment & $\begin{array}{l}\text { Fruits } \\
\text { /plant }\end{array}$ & $\begin{array}{l}\text { Fruit weight } \\
(\mathrm{kg})\end{array}$ & Yield kg/plant & Fruits $/ \mathrm{m}^{2}$ & $\begin{array}{c}\text { Yield } \\
\mathrm{kg} \cdot \mathrm{m}^{-2}\end{array}$ \\
\hline \multicolumn{6}{|c|}{$2011-2012$} \\
\hline 1 (G-CU-HD) & $2.44 \mathrm{a}^{\mathrm{a}}$ & $4.55 b$ & $11.09 \mathrm{~b}$ & $0.67 \mathrm{a}$ & $3.07 \mathrm{~b}$ \\
\hline 2 (G-CU-LD) & $2.82 \mathrm{a}$ & $5.03 \mathrm{a}$ & $14.20 \mathrm{a}$ & $0.38 \mathrm{~b}$ & $1.96 \mathrm{c}$ \\
\hline 3 (G-CI-HD) & $2.66 \mathrm{a}$ & $5.09 \mathrm{a}$ & $13.55 \mathrm{ab}$ & $0.73 \mathrm{a}$ & $3.76 \mathrm{a}$ \\
\hline 4 (G-CI-LD) & $2.55 \mathrm{a}$ & $5.22 \mathrm{a}$ & $13.36 \mathrm{ab}$ & $0.3 \mathrm{bc}$ & $1.51 \mathrm{c}$ \\
\hline 5 (C-UN-HD) & $1.71 \mathrm{~b}$ & $3.05 \mathrm{~d}$ & $3.93 \mathrm{c}$ & $0.47 \mathrm{~b}$ & $1.46 \mathrm{c}$ \\
\hline 6 (C-UN-LD) & $1.66 \mathrm{~b}$ & $3.92 \mathrm{c}$ & $6.52 \mathrm{c}$ & $0.22 \mathrm{c}$ & $0.90 \mathrm{~d}$ \\
\hline $\mathrm{P}$ & $* * *$ & $* * *$ & $* * *$ & $* * *$ & $* * *$ \\
\hline \multicolumn{6}{|c|}{$2012-2013$} \\
\hline 1 (G-CU-HD) & $2.36 \mathrm{~b}$ & $4.92 \mathrm{a}$ & $11.60 \mathrm{~b}$ & $0.65 b$ & $3.22 \mathrm{~b}$ \\
\hline 2 (G-CU-LD) & $2.88 \mathrm{a}$ & $5.40 \mathrm{a}$ & $15.60 \mathrm{a}$ & $0.39 \mathrm{~d}$ & $2.16 \mathrm{c}$ \\
\hline 3 (G-CI-HD) & $2.94 \mathrm{a}$ & $5.25 \mathrm{a}$ & $15.42 \mathrm{a}$ & $0.82 \mathrm{a}$ & $4.28 \mathrm{a}$ \\
\hline 4 (G-CI-LD) & $2.40 \mathrm{~b}$ & $5.40 \mathrm{a}$ & $13.04 \mathrm{~b}$ & $0.33 \mathrm{e}$ & $1.80 \mathrm{~d}$ \\
\hline 5 (C-UN-HD) & $1.83 \mathrm{c}$ & $3.90 \mathrm{~b}$ & $7.15 \mathrm{c}$ & $0.50 \mathrm{c}$ & $1.97 \mathrm{~cd}$ \\
\hline 6 (C-UN-LD) & $2.05 \mathrm{c}$ & $4.22 b$ & $8.68 \mathrm{c}$ & $0.28 \mathrm{e}$ & $1.20 \mathrm{e}$ \\
\hline $\mathrm{P}$ & $* * *$ & $* * *$ & $* * *$ & $* * *$ & $* * *$ \\
\hline
\end{tabular}

$\mathrm{a} * * *$ and $* * *$ represent significance at $\mathrm{P}<0.05,0.01$ and 0.001 , respectively.

Ciênc. Agrotec., Lavras, v. 39, n. 4, p. 323-330, jul./ago., 2015 
Table 5: Total fruit production of the grafted and non-grafted triploid Crunchy Red cultivar and Sangría cultivar.

\begin{tabular}{ccc}
\hline \multirow{2}{*}{ Treatment } & \multicolumn{2}{c}{ Crop season } \\
\cline { 2 - 3 } & $2011-2012$ & $2012-2013$ \\
\hline 1 (G-CU-HD) & $4.26 \mathrm{~b}^{\mathrm{a}, \mathrm{b}}$ & $4.75 \mathrm{~b}$ \\
(G-CU-LD) & $2.65 \mathrm{c}$ & $3.03 \mathrm{c}$ \\
(G-CI-HD) & $5.28 \mathrm{a}$ & $5.98 \mathrm{a}$ \\
(G-CI-LD) & $2.55 \mathrm{c}$ & $2.61 \mathrm{c}$ \\
$5(\mathrm{C}-\mathrm{UN}-\mathrm{HD})$ & $2.07 \mathrm{c}$ & $3.05 \mathrm{c}$ \\
$6(\mathrm{C}-\mathrm{UN}-\mathrm{LD})$ & $1.28 \mathrm{~d}$ & $1.64 \mathrm{~d}$ \\
$\mathrm{P}$ & $* * *$ & $* * *$ \\
\hline
\end{tabular}

a*, ${ }^{* *}$ and $* * *$ represents significance at $\mathrm{P}<0.05,0.01$ and 0.001 , respectively. ${ }^{\mathrm{b}} \mathrm{kg} \mathrm{m}^{-2}$.

Table 6: Qualitative traits of the grafted and non-grafted triploid Crunchy Red watermelons.

\begin{tabular}{|c|c|c|c|c|c|c|}
\hline Treatment & $\begin{array}{l}\text { Soluble solids } \\
\left.\text { ( }{ }^{\circ} \text { Brix }\right)\end{array}$ & $\mathrm{pH}$ & $\begin{array}{l}\text { Pulp firmness } \\
\mathrm{kg} / \mathrm{cm}^{2}\end{array}$ & $\begin{array}{l}\text { Bark width } \\
(\mathrm{cm})\end{array}$ & $\begin{array}{l}\text { Pulp width } \\
\text { (cm) }\end{array}$ & $\begin{array}{c}\text { Moisture } \\
\text { content }(\%)\end{array}$ \\
\hline \multicolumn{7}{|c|}{ 2011-2012 } \\
\hline 1 (G-CU-HD) & 11.72 & 5.20 & $1.94 \mathrm{~cd}^{\mathrm{a}}$ & $1.43 b$ & $15.59 b$ & 91.13 \\
\hline 2 (G-CU-LD) & 11.78 & 5.30 & $2.02 \mathrm{bc}$ & $1.45 \mathrm{~b}$ & $17.63 \mathrm{a}$ & 91.16 \\
\hline 3 (G-CI-HD) & 11.74 & 5.27 & $2.12 \mathrm{a}$ & $1.50 \mathrm{a}$ & $17.29 \mathrm{a}$ & 90.97 \\
\hline 4 (G-CI-LD) & 11.53 & 5.27 & $2.11 \mathrm{ab}$ & $1.45 \mathrm{~b}$ & $17.27 \mathrm{a}$ & 90.94 \\
\hline 5 (C-UN-HD) & 11.46 & 5.29 & $1.86 \mathrm{~d}$ & $1.53 \mathrm{a}$ & $10.67 \mathrm{~d}$ & 91.83 \\
\hline 6 (C-UN-LD) & 11.46 & 5.27 & $1.70 \mathrm{e}$ & $1.53 \mathrm{a}$ & $13.55 \mathrm{c}$ & 91.27 \\
\hline $\mathrm{P}$ & NS & NS & $* * *$ & $* * *$ & $* * *$ & NS \\
\hline \multicolumn{7}{|c|}{$2012-2013$} \\
\hline 1 (G-CU-HD) & 11.58 & 5.23 & $2.09 \mathrm{~b}$ & $1.36 \mathrm{~b}$ & $16.48 \mathrm{ab}$ & $93.46 b c$ \\
\hline 2 (G-CU-LD) & 11.61 & 5.23 & $2.12 b$ & $1.41 \mathrm{ab}$ & $16.78 \mathrm{ab}$ & $92.80 \mathrm{~cd}$ \\
\hline 3 (G-CI-HD) & 11.40 & 5.21 & $2.25 \mathrm{a}$ & $1.48 \mathrm{ab}$ & $16.93 \mathrm{ab}$ & $95.06 \mathrm{a}$ \\
\hline 4 (G-CI-LD) & 11.51 & 5.21 & $2.20 \mathrm{ab}$ & $1.43 \mathrm{ab}$ & $17.38 \mathrm{a}$ & $91.76 \mathrm{~d}$ \\
\hline 5 (C-UN-HD) & 11.40 & 5.17 & $1.96 \mathrm{c}$ & $1.50 \mathrm{a}$ & $15.05 \mathrm{c}$ & $93.23 \mathrm{c}$ \\
\hline 6 (C-UN-LD) & 11.40 & 5.26 & $1.93 \mathrm{c}$ & $1.45 \mathrm{ab}$ & $16.08 \mathrm{bc}$ & $94.46 \mathrm{ab}$ \\
\hline $\mathrm{P}$ & NS & NS & $* * *$ & $*$ & $* *$ & $* * *$ \\
\hline
\end{tabular}

${ }^{a} \mathrm{NS}, *, * *$ and $* * *$ represent nonsignificance or significance at $\mathrm{P}<0.05,0.01$ and 0.001 , respectively.

\section{CONCLUSIONS}

The watermelons that were grafted onto Citrullus lanatus cv Robusta and Cucurbita maxima x Cucurbita moschata cv Super Shintoza exhibited resistance to the pathogen Fusarium oxysporum $\mathrm{f}$. sp. niveum. The watermelons grafted onto Citrullus lanatus $c v$ Robusta showed tolerance to Meloidogyne incognita. The watermelons grafted onto Citrullus lanatus $c v$ Robusta displayed the highest production at the high plant density of 4,167 plants ha- ${ }^{-1}$, followed by watermelons grafted onto Cucurbita maxima $\mathrm{x}$ Cucurbita moschata cv Super Shintoza. The fruit quality was not significantly different between the plants grafted onto Citrullus lanatus cv Robusta and the plants grafted onto Cucurbita maxima x Cucurbita moschata cv Super Shintoza. 


\section{ACKNOWLEDGEMENTS}

The authors wish to express their gratitude to the Dirección General de Educación Superior y Tecnológica (DGEST), now Tecnologico Nacional de Mexico for their support of this research project (Project code: 4611.12P).

\section{REFERENCES}

BEKHRADI, F.; KASHI, A.; DELSHAD, M. Effect of three cucurbits rootstocks on vegetative and yield of Charleston Gray watermelon. International Journal of Plant Production. 5:105-110. 2011.

BOUGHALLEB, N. et al. Resistance evaluation of grafted watermelon (Citrullus lanatus L.) against Fusarium wilt and Fusarium crown and root rot. Asian Journal of Plant Pathology. 2:24-29, 2008.

DAU, V.T. et al. A simplified technique for grafting watermelon onto resistant cucurbit rootstocks for control of Fusarium wilt of watermelon in Nghe An Province, Vietnam. Australasian Plant Disease Notes. 4:114-116, 2009.

DEL PRADO-VERA, I.C.; TOVAR-SOTO, A.; HERNÁNDEZ, J.A. Distribución de especies y razas de Meloidogyne en México. Revista Mexicana de Fitopatología. 19:32-39, 2001.

EL-WANIS, M.M.; AMIN, A.W.; ABDEL, R.T.G. Evaluation of some Cucurbitaceous rootstocks 2-effect of cucumber grafting using some rootstocks on growth, yield and its relation with root-knot nematode Meloidogyne incognita and Fusarium wilt, infection.

Egyptian Journal of Agricultural Research. 91(1):235-257, 2013.

HUITRÓN, M.V. et al. The effect of various rootstocks on triploid watermelon yield and quality. Journal of Food, Agriculture \& Environment. 5(3\&4):344-348, 2007.

HUITRÓN-RAMÍREZ, M.V.; RICARDEZ-SALINAS, M.; CAMACHO-FERRE, F. Influence of grafted watermelon plant density on yield and quality in soil infested with melon necrotic spot virus. HortScience. 44:1838-1841, 2009.

KEINATH, A.P.; HASSELL, R.L. Control of Fusarium wilt of watermelon by grafting onto bottlegourd or interspecific hybrid squash despite colonization of rootstocks by Fusarium. Plant Disease. 98(2):255-266, 2014.

KING, S.R. et al. Grafting for disease resistance.

HortScience. 43:1673-1676. 2008.

LEE, J.M.; ODA, M. Grafting of herbaceous vegetable and ornamental crops. Horticultural Reviews. 28:61124, 2003.

MIGUEL, A. et al. The grafting of triploid watermelon is an advantageous alternative to soil fumigation.

Scientia Horticulturae. 103:9-17, 2004.

ODA, M. New grafting methods for fruits bearing vegetables in Japan. Japan Agricultural Research Quarterly. 29: 187-194, 1995.

RIVERO, R.M.; RUIZ, J.M.; ROMERO, L. Role of grafting in horticultural plants under stress condition. Journal of Food, Agriculture and Environment. 1:7074, 2003.

SCHWARZ, D. et al. Grafting as a tool to improve tolerance of vegetables to abiotic stresses: thermal stress, water stress and organic pollutants. Scientia Horticulturae. 127:162-171, 2010.

SAS INSTITUTE. SAS/STAT user's guide. Release 6.3 ed. SAS Institute, Cary, N.C. 1997.

THIES, J.A.; LEVI, A. Resistance of watermelon germplasm to the peanut root-knot nematode.

HortScience. 38:1417-1421, 2003.

THIES, J.A.; LEVI, A. Characterization of watermelon (Citrullus lanatus var. citroides) germplasm for resistance to root-not nematodes. HortScience. 38:1417-1421, 2007.

TAYLOR, A.L.; SASSER, J.N. Biology, identification and control of root-knot nematodes (Meloidogyne spp.) North Carolina State University and U. S. Agency for International Development, Raleigh, N.C. 1978. 111 p.

YETISIR, H.; SARI, N. Effect of different rootstock on plant growth, yield and quality of watermelon.

Australian Journal of Experimental Agriculture. 43:1269-1274, 2003. 